\title{
Using Multi Agent Systems in Green Supply Chain
}

\author{
Mohamed Dif El Idrissi, Abdelkabir Charkaoui, Abdelwahed Echchatbi
}

\begin{abstract}
Green Supply Chain Management (GSCM) is one the key concepts that organizations need to implement in order to reduce the environmental impact of their activities due to the increase of environmental awareness. However, its implementation is full of constraints in terms of the coordination and collaboration between all stakeholders. Therefore, many GSCM models and frameworks, like the multi agent systems (MAS) are proposed to reduce the complexity level in the Supply Chain. The main objective of this paper is to study the multi agent systems usage for GSCM modelling. The used research methodology is based on a literature review of 50 articles published between 2012 and 2019 in 10 different journals. 5 articles are selected out of 50 because of their accordance with the research subject. The contribution of this paper is to show the benefits of using multi agents systems for GSCM modelling problems.
\end{abstract}

Keywords : Supply Chain Management, Green Supply Chain Management, Multi agent systems.

\section{INTRODUCTION}

In order to increase their competitiveness in global markets, organizations search for enlarging their supply chain around the world, this situation lead to an increase demand of natural resources. Moreover, the increasing attention from customers, stakeholders, governments and environmental organizations push companies to consider environmental impact of their activities. [1] For this reason, companies started to integrate new concepts like GSCM in order to improve their environmental responsibility and make the use of natural resources more rationalized.

Several research works propose dozens of practices of GSCM that can be adopted to improve the Supply Chain performance, but their implementation is full of constraints. As a result, several implementation models such as Multi agent system for GSCM are proposed to facilitate this transition. This research paper intent to answer the following research questions which provides a better understanding of

Revised Manuscript Received on April 21, 2020.

* Correspondence Author

Mohamed Dif El Idrissi*, Mechanical, Industrial Management and Innovation Laboratory, Faculty of Sciences and Technologies, University Hassan First, Settat Morocco. Email: m.difelidrissi@gmail.com

Abdelkabir Charkaoui, Mechanical, Industrial Management and Innovation Laboratory, Faculty of Sciences Technologies, University Hassan First, Settat, Morocco. Email: charkaoui.a@gmail.com

Abdelwahed Echchatbi, Mechanical, Industrial Management and Innovation Laboratory, Faculty of Sciences and Technologies, University Hassan First, Settat, Morocco. Email: echchatbi@gmail.com

(C) The Authors. Published by Blue Eyes Intelligence Engineering and Sciences Publication (BEIESP). This is an open access article under the CC BY-NC-ND license (http://creativecommons.org/licenses/by-nc-nd/4.0/) multi agent system usage in GSCM.

Q1 : to which extent the multi agent systems are used to address GSCM topics?

Q2 : which methodologies are used to design a MAS architecture in GSCM field ?

The organization of the paper is the following. Section 1 presents the theoretical framework, which consists of GSCM and MAS definition. Next, section 2 discusses the adopted methodology to establish this literature review. Section 3 presents the findings of this review. A discussion of the found results is the subject of Section 4. Finally, the paper summarizes the main ideas, precises the contributions and provide a recommendation for future researches.

\section{THEORITICAL FRAMEWORK}

\section{A. Green Supply Chain Management}

Many definitions of the GSCM are provided in the literature, the most used ones define this concept as the consideration and the integration of environmental thinking in the Supply Chain, which include product design, raw materials sourcing, manufacturing process, delivery process to customers and product management after its lifetime [2]. Many GSCM definitions address both economic and environmental considerations, they also highlight the key role of coordination between partners and flows to implement the GSCM successfully. In addition, researchers distinguish between a pure reactive environmental practices and proactive program management. [3]. Therefore, the GSCM is a concept that has evolved a lot in recent years.

The GSCM covers many practices and activities like green design, green procurement, green manufacturing, green distribution and reverse logistics [2].

These activities encompass all processes in the supply chain, from green procurement (supplier selection, raw material selection, etc.) to green manufacturing (green design, waste reduction, energy reduction, etc.). ) up to the ecological logistics, recycling and waste management products. Green procurement can be defined as an environmental purchasing, consisting of activities like recycling and reuse of materials in the purchasing process. Green manufacturing is a production process with low environmental impacts and with less waste or pollution. Green distribution covers green packaging and green logistics. Quality packaging and loading models will significantly reduce the use of materials and space in the warehouse. [4]

\section{B. Multi agent systems}

\section{Published By:}

Blue Eyes Intelligence Engineering \& Sciences Publication

(C) Convriaht: All riahts reserved. 
Multi agent system is a system composed of many agents, which take some specific and dedicated roles. They can interact with each other to solve problems, which exceed the capabilities and the knowledge of an individual agent [5].

These interactions can be simple information exchanges, but also demand for particular actions, cooperation, coordination and negotiation to manage interdependent activities [6]. Many researches advise that agent based models are the most appropriate ones for domains and systems characterized by high degree of location, distribution and dominated by discrete decision [7]. The Supply Chain network has the same characteristics as a multi agent system. In fact, the Supply Chain is composed of several autonomous participants who play specific roles. [8]

Each Supply Chain participant should have its own resources, skills and abilities to perform certain tasks and roles to make products conform to the customers' requirements [9].

Participants in the Supply Chain have basic skills and each of them can neither perform all the activities of the chain nor solve all the problems. Multi-agent systems are identified as a modelling methodology for supply chain management, which aims to deal with bullwhip effects, poor communication results, and poor coordination between members of the supply chain [10].

\section{RESEARCH METHODOLOGY}

The adopted research methodology is to build a literature review to bring knowledge on this topic based on already existing literature [11]. The objective is to show to which extent multi agent systems can be used in the GSCM modelling. 13 per reviewed journals are analyzed within a time frame of six years (2012 - 2019) and the search was done using keywords on Green Supply Chain, Sustainable Supply Chain and Multi Agent Systems. The result of the initial research give a total of 50 articles and 15 articles were selected based on their title. From these 15 articles, 5 articles were selected because of their accordance with the focus and objective of the study. To the best of our knowledge, these articles are the only ones, which used a multi agent approach in the context of Green Supply Chain Management within the pre-defined period. A literature review was done on these 5 articles to address research questions.

\section{FINDINGS}

The overview of the five analyzed articles with their respective methodologies and findings are given in table I.

\section{DISCUSSION}

The Supply Chain network has the same characteristics as a multi agent system. In fact, a supply chain is composed of several autonomous participants who play specific roles along the chain [8]. However, very few studies are used multi agent systems to address GSCM topics [12]. To the best of our knowledge, the above-mentioned researches are the only ones, which considers applicability and suitability of multi agent systems in GSCM field. In addition, only 2 studies out of 5 which developed an integrated framework for the whole Supply Chain, and one of them considers only the context of Small and Medium Enterprises (SMEs). The result of the analyzed articles shows that MAS is able to solve communication and complexity problems in the GSCM field and it helps to introduce sustainability parameters such as the environmental concern into the closed-loop Supply Chain processes.

Concerning the MAS design methodologies, the most used one is the Foundation for Intelligent Physical Agent (FIPA), which consists of definition of the agent architecture and then use of FIPA protocols for the communication and interaction between agents. Multi Agent Logic Language for Encoding Teamwork (MALLET) is an agent language framework, which facilitates and manage agent activities via the proactive exchange of information [17]. ANEMONA is a MAS methodology for holonic manufacturing systems (HMS) design and analysis based on agent notion and HMS requirements [18].

Table- I: Overview of the articles in the literature review.

\begin{tabular}{|c|c|c|c|c|c|c|}
\hline Authors & $\begin{array}{c}\text { Yea } \\
\mathbf{r} \\
\end{array}$ & $\begin{array}{c}\text { GSCM } \\
\text { process }\end{array}$ & $\begin{array}{c}\text { Paper } \\
\text { type }\end{array}$ & Description & $\begin{array}{c}\text { MAS } \\
\text { methodology \& } \\
\text { communication } \\
\text { channel } \\
\end{array}$ & Findings \\
\hline $\begin{array}{c}\text { Mishra, } \\
\text { Kumar } \\
\text { and Chan } \\
\text { [12] }\end{array}$ & 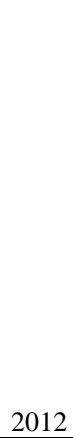 & $\begin{array}{l}\text { Reverse } \\
\text { logistics }\end{array}$ & $\begin{array}{l}\text { Case study } \\
\text { with } \\
\text { empirical } \\
\text { analysis }\end{array}$ & $\begin{array}{l}\text { Solve the } \\
\text { complexity of } \\
\text { including } \\
\text { waste } \\
\text { management } \\
\text { and recycling } \\
\text { in the GSCM }\end{array}$ & MALLET & $\begin{array}{l}\text { Decision } \\
\text { framework } \\
\text { from waste } \\
\text { collection to } \\
\text { the distribution } \\
\text { of the recycled } \\
\text { componenets } \\
\text { to } \\
\text { manufacturing }\end{array}$ \\
\hline
\end{tabular}

Published By:

Blue Eyes Intelligence Engineering

\& Sciences Publication

(C) Convriaht: All riahts reserved. 


\begin{tabular}{|c|c|c|c|c|c|c|}
\hline$\frac{\text { Fu-Shiung }}{\frac{\text { Hsieh }}{[13]}}$ & 2015 & All processes & $\begin{array}{c}\text { Case study } \\
\text { with } \\
\text { empirical } \\
\text { analysis } \\
\end{array}$ & $\begin{array}{l}\text { Propose a } \\
\text { framework to } \\
\text { configure } \\
\text { sustainable } \\
\text { Supply Chain } \\
\text { network } \\
\text { quickly and } \\
\text { efficiently. }\end{array}$ & FIPA & $\begin{array}{l}\text { MAS helps to } \\
\text { solve } \\
\text { scheduling } \\
\text { problem for } \\
\text { sustainable } \\
\text { supply chain. }\end{array}$ \\
\hline $\begin{array}{c}\text { Giret and } \\
\text { Salido } \\
\text { [14] }\end{array}$ & 2017 & $\begin{array}{c}\text { Green } \\
\text { manufacturin } \\
\mathrm{g}\end{array}$ & $\begin{array}{l}\text { Case study } \\
\text { with } \\
\text { empirical } \\
\text { analysis }\end{array}$ & $\begin{array}{c}\text { Develop } \\
\text { Sustainable } \\
\text { manufacturin } \\
\text { g system } \\
\text { platform } \\
\text { supported by } \\
\text { intelligent } \\
\text { software } \\
\text { agents }\end{array}$ & ANEMONA & $\begin{array}{l}\text { MAS help to } \\
\text { include } \\
\text { sustainability } \\
\text { in } \\
\text { manufacturing } \\
\text { systems }\end{array}$ \\
\hline $\begin{array}{c}\text { Ghadimi, } \\
\text { Toosi and } \\
\text { Heavey } \\
\text { [15] }\end{array}$ & 2018 & $\begin{array}{c}\text { Green } \\
\text { procurement }\end{array}$ & $\begin{array}{l}\text { Case study } \\
\text { with } \\
\text { empirical } \\
\text { analysis }\end{array}$ & $\begin{array}{c}\text { Structured } \\
\text { information } \\
\text { exchange } \\
\text { processes to } \\
\text { make better } \\
\text { sustainable } \\
\text { procurement } \\
\text { decisions by } \\
\text { maintaining a } \\
\text { long term } \\
\text { partnership } \\
\text { between the } \\
\text { manufacturer } \\
\text { and its } \\
\text { suppliers. }\end{array}$ & FIPA & $\begin{array}{l}\text { MAS is able to } \\
\text { reduce } \\
\text { communicatio } \\
\mathrm{n} \text { and } \\
\text { information } \\
\text { exchange } \\
\text { problems in the } \\
\text { sustainable } \\
\text { suppliers } \\
\text { selection } \\
\text { process }\end{array}$ \\
\hline $\begin{array}{c}\text { A, Ben } \\
\text { Mekki, J. } \\
\text { Tounsi, L. } \\
\text { Ben Said [16] }\end{array}$ & 2019 & All processes & $\begin{array}{c}\text { Research } \\
\text { paper with } \\
\text { conceptua } \\
\text { l model }\end{array}$ & $\begin{array}{c}\text { Intelligent } \\
\text { dynamic } \\
\text { system based } \\
\text { on agents } \\
\text { interaction to } \\
\text { study } \\
\text { sustainability } \\
\text { in the context } \\
\text { of SMEs }\end{array}$ & FIPA & $\begin{array}{l}\text { MAS helps to } \\
\text { highlight the } \\
\text { sustainability } \\
\text { assessment } \\
\text { process in } \\
\text { SME context }\end{array}$ \\
\hline
\end{tabular}

\section{CONCLUSION}

In this paper, we present a literature review on recent studies using multi-agent systems in the field of GSCM. The work proposed in this paper attempts to establish a literature review within a period from 2012 to 2019. 5 articles were selected out of 50 and help us to show the benefits of using multi agent systems in GSCM. It was also noticed most of the existing works do not integrate all the GSCM processes and focus only on some dedicated ones. In conclusion, the proposed work can provide a good methodological basis for solving the GSCM modelling and collaboration problem based on the multi agent approach. The proposal of other frameworks based on the multi-agent approach can be proposed as a perspective for future research.

\section{REFERENCES}

1. M.Koho, M. Tapaninaho, J. Heilala, and S. Torvinen, "Towards a concept for realizing sustainability in the manufacturing industry," Journal of Industrial and Production Engineering, vol.32, no.1, pp. 12-22, 2015
2. S.K. Srivastava, "Green supply-chain management: a state of the art literature review," International Journal Management Reviews, vol. 9, pp. 53-80, 2007

3. Q. Zhu, J. Sarkis, "Relationships between operational practices and performance among early adopters of green supply chain management practices in Chinese manufacturing enterprises," Journal of Operations Management, vol. 22, pp. 265-289, 2004

4. M.L. Tseng, Md. S. Islam, N. Karia, F. A. Fauzi, S. Afrin, «A literature review on green supply chain management : trends and future challenges," Resources, Conservation and Recycling, vol. 141, pp. 145-162, 2019

5. M. Wooldridge, An Introduction to Multi Agent Systems, John Wiley and Sons, New York, 2009

6. N.R. Jennings, "On agent based software engineering," Artificial Intelligence, vol. 117, pp. 277-296, 2000

7. H.V.D. Parunak, R. Savit, R. L. Riolo, « Agent based modeling vs. equation based modeling : A case study and users guide," Proceeding of Simulation, Springer, Paris, France, 1998, pp.10-26

8. S. Chopra, P. Meindl, Supply cham management: Strategy, Planning, and Operation, Person and Prentice Hall, New Jersey, 2004.

9. D. Simchi Levi, P. Kaminsky, E. Simchi Levi, Designing \& managing the supply chain concepts, strategies \& case studies, McGraw Hill/Irwin, New York, 2003.

10. R. Pino, I. Fernandez, D. Fuente, J. Parreno, P. Priore, "Supply chain modelling using a multi agent system," Journal of Advances in Management Research, vol. 7, pp. 149-162, 2010

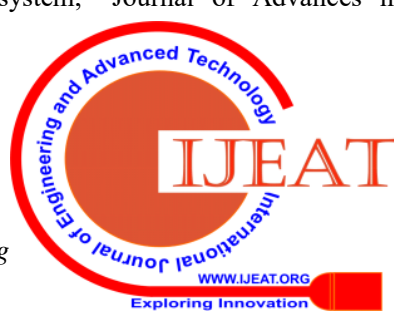


11. K. Williamson, Two major traditions of research, In search methods for students, academics and professionals : information management and systems, Wagga Wagga, 2002

12. N. Mishra, V. Kumar and F.T.S. Chan "A multi agent architecture for reverse logistics in a green supply chain," International Journal of Production Research, vol. 50, no. 9, pp.2396-2406, 2012

13. F. Hsieh, "Scheduling sustainable supply chains based on multi agent systems and workflow models, 10th International Conference on Intelligent Systems and Knowledge Engineering, Taipei, pp. 252-259, 2015

14. A. Giret, D. Trentesaux, M.A. Salido, E. Garcia, E.Adam, "A holonic multi agent methodology to design sustainable intelligent manufacturing control systems," Journal of cleaner production, vol. 167, pp. 1370-1386, 2017

15. P. Ghadimi, F.G. Toosi, C. Heavey, “ A multi agent systems approach for sustainable supplier selection and order allocation in a partnership supply chain, “European Journal of Operational Research, vol. 269, pp. 286-301, 2018

16. A. Ben Mekki, J. Tounsi, L. Ben Said, "Fuzzy Multi Agent approach for monitoring SMEs sustainable SC under uncertainty," Procedia Computer Science, vol. 164, pp. 245-250, 2019

17. X. Fan, J. Yen, M. Miller, T. R. Ioerger, R. Volz, "MALLET - a multi agent logic language for encoding teamwork," IEEE Transactions on Knowledge and Data Engineering, vol. 18, no. 1, pp. 123-138, 2006

18. V. Botti, A. Giret, ANEMONA A Multi agent methodology for holonic manufacturing systems. Springer, London, 2008

\section{AUTHORS PROFILE}

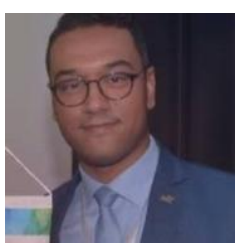

Mohamed Dif El Idrissi, PhD candidate in Green Supply Chain Management. He prepares his $\mathrm{PhD}$ in the Mechanical, Industrial Management and Innovation Laboratory at the Faculty of Sciences and Technologies, University Hassan First, Settat Morocco. He got an engineer degree in Logistics and Transportation in 2015. The main research area of his PhD are: Green Supply Chain Management, Supply Chain performance, Multi Agent Systems.

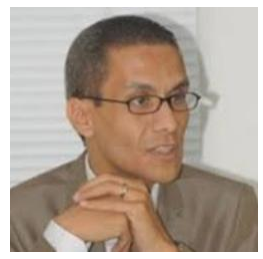

Abdelkabir Charkaoui PhD has a baccalaureate general certificate of secondary education in Mathematics sciences, a Bachelor's degree in Computer Science of Management and a Graduate Degree in logistics engineering. He received his $\mathrm{PhD}$ in Logistics \& SCM from Cadi Ayyad University of Marrakesh. At present, he is working as an Assistant Professor in Hassan 1st University, Faculty of Science and Technology - Settat, Morocco. Department of Mechanical Engineering, Laboratory Industrial Management and Innovation (LIMMII). His research interests are in operations management, logistics performance and maturity of Lean Manufacturing. Also, hi is responsible of Team Research : Operations Management and Supply Chain.

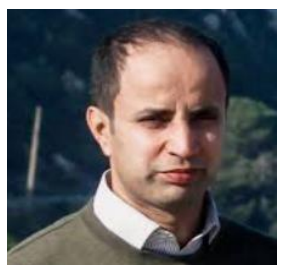

Abdelwahed Echchatbi PhD from Mohamadia Engineering School in Industrial engineering. At present, he is PES at Hassan 1st University, Faculty of Science and Technology - Settat, Morocco. Department of Mechanical Engineering, director of Laboratory Industrial Management and Innovation (LIMMII). Research interests are in operations management,

optimization and simulation. 